\title{
PENGEMBANGAN SUMBER DAYA MANUSIA DALAM MENDUKUNG PROGRAM KONSERVASI LINGKUNGAN LAGUNA SEGARAANAKAN
}

\author{
Oleh : Asep Mulyadi
}

\begin{abstract}
ABSTRAK
Pendangkalan dan penyempitan Laguna Segara Anakan telah mengakibatkan rentetan kejadian seperti penurunan hasil tangkapan ikan- kemiskinan penduduk degradasi hutan mangrove akibat penebangan liar. Keadaan ini sudah pada tingkat yang kritis, sehingga dikhawatirkan potensi-potensi tersebut hanya tinggal kenangan. Upaya perbaikan dan peningkatan kualitas kawasan telah dilakukan oleh pemerintah, namun hasilnya belum optimal. Salah satu faktor terpenting dari masalah ini adalah tingkat partisipasi masyarakat di daerah hulu dari Daerah Aliran Sungai yang bermuara ke Laguna Segara Anakan, dalam berinteraksi dengan lingkungan (lahan) dimana mereka tinggal.

Tujuan penelitian ini adalah ingin menyempurnakan bentuk-bentuk partisipasi masyarakat yang lebih tepat dan efektif bagi usaha konservasi di ligkungan kawasan hulu DAS secara keseluruhan. Pertanyaan penelitian yang diajukan adalah (1) Seberapa besar tingkat partisipasi masyarakat dalam upaya konservasi terkait dengan ekosistem Laguna Segara Anakan? (2) Bagaimana bentuk partisipasi masyarakat dilakukan terhadap upaya konservasi di lingkungannya? (3) Apakah ada perbedaan bentuk partisipasi antara masyarakat di Kecamatan Padaherang dengan Cimanggu?
\end{abstract}

Metode yang digunakan dalam penelitian ini adalah survey dan analisis penelitian dilakukan secara deskriptif.

Hasil penelitian adalah secara keseluruhan, tingkat partisipasi masyarakat di kedua wilayah belum menunjukkan tingkat partisipasi sebagaimana yang diharapkan, hal tersebut ditunjukkan oleh tingkat persentase yang masih rendah dari seluruh variabel partisipasi, namun demikian secara parsial menunjukkan sebagai berikut: (1) Terkait dengan ide atau gagasan dalam rencana kegiatan konservasi ini cukup baik ditunjukkan oleh penduduk di kecamatan Cimanggu. Hal tersebut dimungkinkan karena terkait dengan tingkat pendidikan penduduk dan tingkat pengetahuan penduduk, dimana penduduk dengan tingkat pendidikan tinggi lebih banyak terdapat di Cimangu dari pada Padaherang; (2) Bentuk partisipasi barang, proporsi tertinggi terdapat di kecamatan Cimanggu yaitu pada kegiatan penghijauan hutan. Akan tetapi nilai persentasi yang tinggi di kecamatan Padaherang yaitu pada kegiatan sosialisasi konservasi; (3) Bentuk partisipasi uang bila dilihat secara keseluruhan kecamatan Cimanggu yang paling tinggi; (4) Bentuk partisipasi tenaga yang tinggi, juga diperlihatkan oleh kecamatan Cimanggu Hal ini dimungkinkan karena jumlah penduduk Cimanggu yang lebih besar daripada kecamatan Padaherang; (5)Namun di kecamatan Padaherang dalam kegiatan penyediaan prasarana kesehatan memilki nilai yang tinggi,hal tersebut dimungkinkani terjadi karena masyarakatnya lebih apresiasi tentang kesehatan; (6) Berhubungan dengan keahlian masyarakat identik dengan pendidikan yang dimilki

*) Drs. Asep Mulyadi adalah Dosen Jurusan Pendidikan Geografi FPIPS-UPI 
oleh setiap individu. Dalam bentuk keahlian posisi yang tinggi di kecamatan Padaherang yaitu pada kegiatan penanaman lahan pekarangan sedangkan di kecamatan Cimanggu pada kegiatan menjaga kebersihan lingkungan; (7) Partisipasi dalam bentuk sosial, di kecamatan Padaherang masyarakat memiliki tingkat partisipasi yang lebih tinggi dalam memfasilitasi/menjaga fasilitas pendidikan sedangkan dikecamatan Cimanggu masyarakat lebih berpartisipasi dalam menjaga keberadaan hutan hal ini disebabkan karena fasilitas pendidikan di Cimanggu lebih sedikit dibandingkan dengan Padaherang.

Kata Kunci: Pengembangan sumberdaya manusia, Konservasi lingkungan, Laguna Sagaraanakan.

\section{Pendahuluan}

Laguna Sagara Anakan merupakan salah satu contoh laguna paling menarik di dunia, laguna ini terbentuk oleh proses tektonik, bukan semata-mata oleh proses sedimentasi sebagaimana pada laguna yang biasa terbentuk oleh pulau penghalang (barrier island) sebagai salah satu penciri laguna, oleh karena itu pendangkalan dan sedimentasi yang terjadi di sagara anakan tidak hanya menjadi topik yang hangat dibicarakan oleh praktisi lingkungan di Indonesia saja tetapi sudah menjadi topik yang dibicarakan oleh kalangan internasional. Penyempitan Sagara Anakan sudah menjadi kekhawatiran semua pihak karena laguna sagara anakan mempunyai lingkungan yang menarik, di daerah ini hidup beberapa biota laut (reptil, burung, dan ikan) dan sebagai daerah tangkapan ikan. Dalam beberapa tahun belakang ini laguna sagara anakan mulai mengecil akibat sedimentasi, bahkan sedimen yang masuk ke dalam laguna mengandung bahan non-organik (sampah). Untuk menanggulangi hal ini maka sudah ada beberapa pihak yang mulai berusaha untuk mengurangi dan menanggulangi penyempitan di sagara anakan ini, antara lain pemerintah kabupaten Ciamis, untuk menanggulangi penyempitan dan pendangkalan segara anakan pemerintah kabupaten ciamis akan melakukan penyodetan Citanduy ke arah Samudera Indonesia, sehingga bahan non-organik akan langsung ke arah Samudera Indonesia, tidak lagi masuk ke laguna. Akan tetapi hal ini perlu dikaji lebih lanjut karena penyodetan Citanduy akan memberikan dampak yang sangat besar terutama bagi penduduk di daerah yang akan terkena program penyodetan, untuk itu perlu kajian yang lebih mendalam bagaimana cara melestarikan fungsi sagara anakan sebagai daerah konservasi untuk lingkungan hidup bagi beberapa biota langka.

Pendangkalan dan penyempitan Laguna Segara Anakan juga telah mengakibatkan rentetan kejadian seperti penurunan hasil tangkapan ikankemiskinan penduduk - degradasi hutan mangrove akibat penebangan liar. Keadaan ini sudah pada tingkat yang kritis, sehingga dikhawatirkan potensi-potensi tersebut hanya tinggal kenangan. Upaya perbaikan dan peningkatan kualitas kawasan telah dilakukan oleh pemerintah, namun hasilnya belum optimal. Beberapa bagian program yang dilakukan di kawasan Laguna belum berhasil 
dilakukan, hal tersebut disebabkan baik karena faktor masyarakat yang kurang respek maupun pelaksanaan kebijakan pemerintah yang 'dilematis" seperti pembangunan infra struktur untuk penduduk di kawasan konservasi. Tentunya hal tersebut akan memicu perkembangan wilayah yang semestinya tidak terjadi di daerah yang ditetapkan sebagai kawasan konservasi. Faktor terpenting dari masalah ini adalah tingkat sedimentasi sungai-sungai besar terutama Citanduy yang bermuara ke kawasan tersebut, dan tingginya tingkat sedimentasi diakibatkat oleh dinamika perilaku masyarakat di kawasan hulu sungai tersebut dalam berinteraksi dengan lingkungan (lahan) dimana mereka tinggal. Kepedulian masyarakat yang tinggal di daerah hulu terhadap upaya konservasi lahan di lingkungannya, adalah suatu bentuk sumber daya manusia yang sangat penting bagi terwujudnya kelestarian kawasan Laguna Segara Anakan di daerah hilirnya. Wilayah Kecamatan Padaherang di kabupaten Ciamis Jawa Barat dan kecamatan Cimanggu di kabupaten Cilacap Jawa Tengah, merupakan dua wilayah kecamatan yang berada pada hulu DAS Citanduy. Untuk itu, mengetahui seberapa besar tingkat partisipasi masyarakat di kedua daerah ini terhadap upaya konservasi lingkungan atau lahan di masing-masing wilayah ini, adalah sesuatu yang menarik dan penting untuk di teliti.
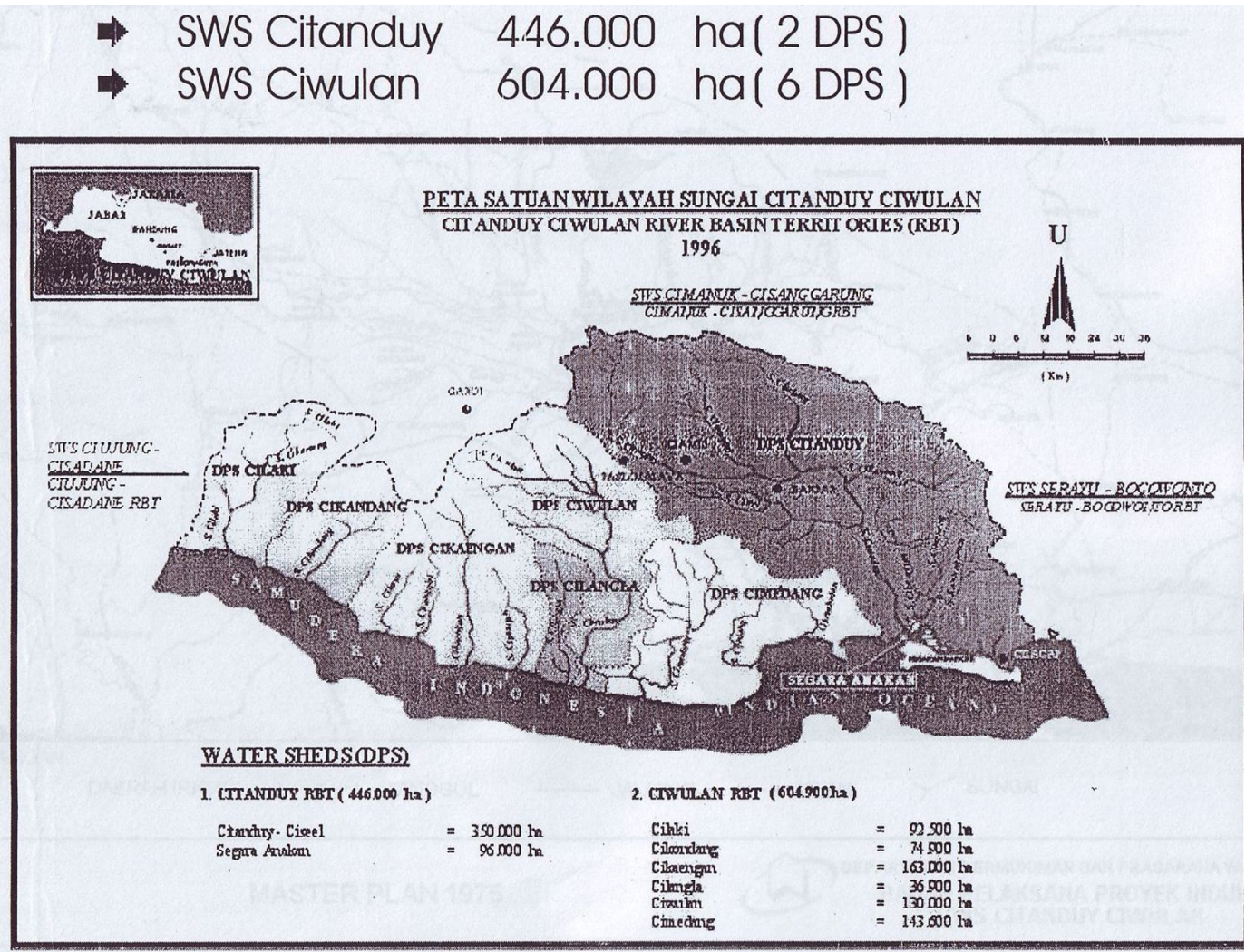

*) Drs. Asep Mulyadi adalah Dosen Jurusan Pendidikan Geografi FPIPS-UPI 


\section{Rumusan Masalah}

Berdasarkan uraian latar belakang masalah yang dikemukan pada bagian pendahuluan, dapat dirumuskan masalah dalam penelitian ini adalah :

1) Seberapa besar tingkat partisipasi masyarakat dalam upaya konservasi terkait dengan ekosistem Laguna Segara Anakan?

2) Bagaimana bentuk partisipasi masyarakat terhadap upaya konservasi di lingkungannya?

3) Apakah ada perbedaan bentuk partisipasi antara masyarakat di Kecamatan Padaherang dan di Cimanggu?

\section{Tujuan Penelitian}

Tujuan penelitian ini antara lain adalah :

1) Mengetahui seberapa besar partisipasi masyarakat dalam kegiatan konservasi di kecamatan Padaherang dan Cimanggu, sehingga diperoleh tingkat ke pedulian dan berbagai alasan yang memposisikan kualitas tingkat partisipasinya

2) Ingin menyempurnakan bentuk-bentuk partisipasi masyarakat yang lebih tepat dan disukai masyarakat di masing-masing wilayah namun hasilnya efektif bagi usaha konservasi di ligkungan kawasan hulu DAS secara keseluruhan.

\section{Metode Penelitian}

Lokasi penelitian dilakukan di dua kecamatan yang merupakan DAS Citanduy hulu yaitu kecamatan Padaherang di kecamatan Ciamis, dimana di daerah itu mengalir sungai Ciseel yang merupakan hulu sungai citanduy dan di kecamatan Cimanggu kabupaten di Cilacap, di daerah ini mengalir sungai Cikawung yang juga merupakan hulu dari sungai Citanduy.

Pengumpulan data dilakukan melalui observasi/pengamatan, wawancara (interview), studi pustaka, dan studi dokumentasi. Observasi dilakukan pada obyek terutama lingkungan fisikal dan lahan di wilayah kecamatan Padaherang dan Cimanggu. Wawancara dilakukan kepada masyarakat yaitu petani, pedagang dan pengusaha dengan cara purposive sampling. Sedangkan analisis data dilakukan dengan metode deskriptif. Dari data baik sekunder maupun primer tersebut diharapkan dapat memberikan informasi tentang seberapa jauh keterlibatan masyarakat dalam upaya konservasi, bentuk-bentuk partisipasi, serta perbandingan tingkat partisipasi masyarakat dalam konservasi antara masyarakat di kecamatan Padaherang dan Cimanggu.

\section{Tinjauan Pustaka}

\section{a. Pengertian Partisipasi Masyarakat}

Ditinjau secara etimologis kata partisipasi merupakan pinjaman dari Bahasa Belanda " Participate", dari Bahasa Inggris “ Participation”. Dalam kamus Bahasa Indonesia (Suryadi.S.Y, 1984:210). Persepsi umum dapat ditangkap mengenai partisipasi dalam proses pembangunan adalah keikutsertaan rakyat dalam programprogram pembangunan. (king.Y.1974:14). Banyak ahli yang memberikan 
pengertian atau batasan tentang partisipasi, namun demikian pada intinya partisipasi memiliki unsur-unsur : (1) adanya keterlibatan secara utuh dari pribadipribadi (2) adanya kesediaan memberikan sumbangan dalam bentuk apapun sehingga tanggung jawab ini melahirkan tindakan atau partisipasi yang tidak dipaksa atau dipaksakan.

Rusidi manyatakan (1993:2) keterlibatan masyarakat dalam kegiatankegiatan yang bersangkutan dengan kepentingan umum dengan cara menyumbangkan pikiran, ide, materi dan tenaga dibedakan menjadi: (a) Partisipasi Pikiran (b) Partisipasi materi (c) Partisipasi Tenaga.

Menurut Prayogo (1976:47) partisipasi masyarakat dibedakan menjadi dua jenis yaitu: partisipasi masyarakat secara sadar memang diarahkan meliputi pembangunan secara gotong royong. Sedangkan partisipasi penduduk secara tidak langsung meliputi pemeliharaan kebersihan lingkungan dan pembinaan keindahan. Menurut Sofiyanto (2006:42)

1) Proses kegiatan mencakup: (a). Inisiasi, ketika gagasan melakukan suatu proyek pembangunan muncul baik pada seseorang atau kelompok dalam komunitas. Gagasan itu kemudian ditularkan ke lingkup yang lebih luas melalui perangkat yang ada, (b). Legitimasi, gagasan untuk melakukan pembangunan memperoleh keabsahan dari komunitas yang bersangkutan. Keabsahan itu dapat diperoleh melalui mekanisme musyawarah atau perundingan baik yang bersifat formal maupun yang bersifat nonformal, (c). Eksekusi, semua kegiatan untuk mewujudkan proyek pembangunan dilaksanakan melalui proses perencanaan, implementasi, pengendalian dan monitoring serta evaluasi.

2) Wujud partisipasi dapat dinyatakan dalam bentuk tenaga, uang (materi) atau pemikiran. Wujud antara komunitas masyarakat yang satu dengan yang lain akan berbeda.

Menurut Pasaribu dan Simanjuntak (1986:265) jenis partisipasi terbagi kedalam:

1) Partisipasi buah pikiran. Diberikan orang dalam Anjangsono, rapat, atau pertemuan dengan cara memberikan saran-saran, pendapat, nasehat, gagasan, ide pemikiran dan sejenisnya.

2) Partisipasi tenaga. Diberikan dalam berbagai kegiatan untuk perbaikan, pertolongan bagi orang lain dengan cara menyumbangkan tenaga dalam kegiatan tersebut.

3) Partisipasi harta benda. Diberikan dalam berbagai kegiatan untuk perbaikan, pertolongan bagi orang lain dengan cara menyumbangkan materi, uang atau harta benda yang dimiliki.

4) Partisipasi keterampilan dan kemahiran. Diberikan untuk mendorong aneka ragam bentuk usaha dan industri dengan cara antara lain melalui penciptaan produk-produk baru yang disebut inivatif.

5) Partisipasi sosial. Diberikan orang sebagai tanda paguyuban melalui turut dalam arisan koperasi, layad (dalam peristiwa kematian), kondangan, dan nyambungan (dalam hajatan) dan sebagainya.

*) Drs. Asep Mulyadi adalah Dosen Jurusan Pendidikan Geografi FPIPS-UPI 
Menurut sifatnya, partisipasi dapat dibedakan menjadi dua yaitu partisipasi aktif dan partisipasi pasif. Suwantoro (2004:85) yaitu sebagai berikut:

Partisipasi aktif dilaksanakan secara langsung baik secara perorangan maupun secara bersama-sama, yang secara sadar ikut membantu program pemerintah dengan inisiatif dan kreasi mau melibatkan diri dalam kegiatan atau melalui rasa ikut memiliki dikalangan masyarakat.

Partisipasi pasif adalah timbulnya kesadaran masyarakat untuk tidak melakukan kegiatan-kegiatan yang dapat mengganggu atau merusak lingkungan alam. Dalam peran pasif masyarakat cenderung sekedar melaksanakan perintah dan mendukung terpeliharanya konservasi sumber daya alam. Upaya peningkatan peran serta pasif dapat dilakukan melalui penyuluhan maupun dialog dengan aparat pemerintah, penyebaran informasi mengenai pentingnya upaya pelestarian sumber daya alam.

Ada beberapa syarat keberhasilan partisipasi masyarakat seperti yang dikemukakan oleh Davis (1989:183) yaitu:

1) Tersedianya waktu yang cukup untuk melakukan partisipasi

2) Manfaatnya lebih besar

3) Relevan dengan kepentingan

4) Kemampuan yang memadai untuk menangani bidang garapan partisipasi

5) Kemampuan berkomunikasi timbal balik

6) Tidak timbul perasaan terancam bagi kedua belah pihak

7) Masih dalam bidang keleluasaan pekerjaan

Untuk meningkatkan partisipasi masyarakat ada beberapa prinsip yang harus diperhatikan yaitu:

1) Cakupan: semua orang, atau wakil-wakil dari semua kelompok yang terkena dampak dari hasil-hasil suatu keputusan atau proses proyek pembangunan misalnya.

2) Kesetaraan dan kemitraan (Equal Partnership). Pada dasarnya setiap orang mempunyai keterampilan, kemampuan dan prakarsa serta mempunyai hak untuk menggunakan prakarsa tersebut terlibat dalam setiap proses guna membangun dialog tanpa memperhitungkan jenjang dan struktur masingmasing pihak.

3) Transportasi: semua pihak harus dapat menumbuh kembangkan komunikasi dan iklim berkomunikasi terbuka dan kondusif sehingga menimbulkan dialog.

4) Kesetaraan kewenangan (Sharing power / Equal powership). Berbagai pihak yang terlibat harus dapat menyeimbangkan distribusi kewenangan dan kekuasaan untuk menghindari terjadinya dominasi.

5) Kesetaraan tanggung jawab (Sharing responsibility). Berbagi pihak mempunyai tanggung jawab yang jelas dalam setiap proses karena adanya kesetaraan kewenangan (sharing power) dan keterlibatannya dalam proses pengambilan keputusan dan langkah-langkah selanjutnya.

6) Pemberdayaan (Empowerment). Keterlibatan berbagai pihak tidak lepas dari segala kekuatan dan kelemahan yang dimiliki setiap pihak, sehingga melalui

*) Drs. Asep Mulyadi adalah Dosen Jurusan Pendidikan Geografi FPIPS-UPI 
keterlibatan aktif dalam setiap proses kegiatan, terjadi suatu proses saling belajar dan saling memberdayakan satu sama lain.

7) Kerjasama. Diperlukan adanya kerjasama berbagai pihak yang terlibat untuk saling berbagi kelebihan guna mengurangi berbagai kelemahan yang ada, khususnya yang berkaitan dengan kemampuan sumberdaya manusia.

\section{b. Konservasi}

Tanah dan air merupakan sumberdaya yang paling fundamental yang dimilki oleh manusia. Tanah merupakan media utama dimana manusia bisa mendapatkan sumber pangan, sandang, papan, tambang, dan tempat dilaksanakanya berbagai aktifitas.

Erosi tanah merupakan suatu masalah bagi keberlangsungan produktifitas lahan, dengan terjadi erosi tanah maka akan terjadi pengurangan ketersediaan air, nutrisi, bahan organic, dan menghambat kedalaman perakaran, sebagai besar air menghilanng dalam bentuk aliran permukaan yang sangat cepat. Erosi tanah juga mengurangi kemampuan tanah menahan air karena partikel-partikel lembut dan bahan organic pada tanah yang terangkuk. Selain mengurngi prosuktifitaas lahan dimana erosi terjadi, erosi tanah juga menyebabkan problem lingkungan yang serius di daerah hilirnya.ssendimen hasil erosi mengngendap dan mendangkalkan sungai-sungai, danau, dan waduk. Untuk mengatasi hal tersebut maka dilakukkan konservasi lahan:

Konservasi banyak kalangan mengartikan adalah "perlindungan terhadap", baik itu terhadap hutan, kawasan pesisir maupun laut. Ada pula yang mengartikan bahwa kawasan konservasi adalah kawasan yang tidak boleh sama sekali diganggu. Kini arti konservasi mulai digeserkan kembali dalam arti " perlindungan, pengawetan maupun pemanfaatan".

Mengingat muara permasalahan dalam penelitian ini adalah proses pendangkalan di perairan Laguna Segara Anakan sebagai akibat laju tingkat erosi tanah di daerah hulu begitu tinggi, maka konservasi lahan atau tanah di daerah hulu menjadi beritu penting. Tujuan utama konservasi tanah adalah untuk mendapatkan tingkat keberlanjutan produksi lahan dengan menjaga laju kehilangan tanah tetap dibawah ambang batas yang diperkenankan, yang secara teoritis dapat dikatakan bahwa laju erosi harus lebih kecil atau sama dengan laju pembentukan tanah. Karena erosi merupakan proses alam yang tidak dapat dihindari sama sekali atau nol erosi, khususnya untuk lahan pertanian, maka yang dapat dilakukan adalah mengurangi erosi sampai batas yang dapat diterima (maximum acceptable limit).

Secara garis besar metode konservasi tanah dapat dikelompokkan menjadi tiga golongan utama, yaitu (1) secara agronomis, (2) secara mekanis, dan (3) secara kimia.

Metode agronomis atau biologi adalah memanfaatkan vegetasi untuk membantu menurunkan erosi lahan. Metode mekanis atau fisik adalah konservasi yang berkonsentrasi pada penyiapan tanah supaya dapat ditumbuhi vegetasi yang lebat, dan cara memanipulasi topografi mikro untuk mengendalikan aliran air dan angin. Sedangkan metode kimia adalah usaha konservasi yang ditujukan untuk

*) Drs. Asep Mulyadi adalah Dosen Jurusan Pendidikan Geografi FPIPS-UPI 
memperbaiki struktur tanah sehingga lebih tahan terhadap erosi. Atau secara singkat dapat dikatakan metode agronomis ini merupakan usaha untuk melindungi tanah, mekanis untuk mengendalikan energi aliran permukaan yang erosif, dan metode kimia untuk meningkatkan daya tahan tanah.

\section{Pengembangan Masyarakat (Community Development)}

Pengembangan masyarakat (community development) merupakan wawasan dasar bersistem tentang asumsi perubahan sosial terancang yang tepat dalam kurung waktu tertentu. Sedangkan teori dasar pengembangan masyarakat yang menonjol pada saat ini adalah teori ekologi dan teori Sumber daya manusia. Teori ekologik mengemukakan tentang "batas pertumbuhan". Untuk sumber-sumber yang tidak dapat diperbaruhi perlu dikendalikan pertumbuhannya. Teori ekologik menyarankan kebijaksanaan pertumbuhan diarahkan sedemikian rupa sehingga dapat membekukan proses pertumbuhan (zero growth) untuk produksi dan penduduk.

Teori Sumber daya manusia memandang mutu penduduk sebagai kunci pembangunan dan pengembangan masyarakat. Banyak penduduk bukan beban pembangunan bila mutunya tinggi. Pengembangan hakikat manusiawi hendaknya menjadi arah pembangunan. Perbaikan mutu sumber daya manusia akan menumbuhkan inisiatif dan kewirausahaan. Teori sumber daya manusia diklasifikasikan kedalam teori yang menggunakan pendekatan yang fundamental.

Community development juga bisa didefinisikan sebagai pertumbuhan, perkembangan dan kemajuan masyarakat lingkungan dalam aspek material dan spiritual tanpa merombak keutuhan komunitas dalam proses perubahannya. Keutuhan komunitas dipandang sebagai persekutuan hidup atas sekelompok manusia dengan karakteristik: terikat pada interaksi sosial, mempunyai rasa kebersaman berdasarkan genealogis dan kepentingan bersama, bergabung dalam satu identitas tertentu, taat pada norma-norma kebersamaan, menghormati hak dan tanggung jawab berdasarkan kepentingan bersama, memiliki kohesi sosial yang kuat, dan menempati lingkungan hidup yang terbatas.

Pengembangan masyarakat (community development) sebagai salah satu model pendekatan pembangunan (bottoming up approach) merupakan upaya melibatkan peran aktif masyarakat beserta sumber daya lokal yang ada. Dan dalam pengembangan masyarakat hendaknya diperhatikan bahwa masyarakat punya tradisi, dan punya adat-istiadat, yang kemungkinan sebagai potensi yang dapat dikembangkan sebagai modal sosial.

Secara umum ada beberapa pendekatan dalam pengembangan masyarakat, diantaranya adalah:

1) Pendekatan potensi lingkungan, hal ini berkaitan dengan daya dukung lingkungan yang ada pada masyarakat setempat.

2) Pendekatan Kewilayahan, hal ini berkaitan dengan pengembangan terhadap wilayah dalam arti kesesuaian dengan wilayahnya (desa/kota) terhadap hal yang akan dikembangkan.

*) Drs. Asep Mulyadi adalah Dosen Jurusan Pendidikan Geografi FPIPS-UPI 
3) Pendekatan kondisi fisik, lebih pada kondisi fisik manusianya.

4) Pendekatan ekonomi, hal ini berkaitan dengan peningkatan pendapatan masyarakat.

5) Pendekatan politik.

6) Pendekatan Manajemen, Pendekatan ini dilakukan dengan melakukan pndataan terhadap potensi, kekuatan dan kelemahan yang ada dalam masyarakat kemudian dilakukan dengan perencanaan, pengorganisasian, penggerakan, bugeting dan controlling. Model pendekatan ini sebenarnya dapat dilakukan dalam masyarakat yang bermacam-macam (pedesaan, perkotaan, marjinal, dan lain-lain).

Pada bagian terdahulu selalu dinyatakan berulang-ulang bahwa proses community development tidak bisa terlepas dari adanya pelibatan masyarakat dalam setiap langkahnya. Pentingnya partisipasi ini didasarkan kepada pandangan bahwa dengan partisipasi masyarakat maka:

1) lebih banyak hasil kerja yang dicapai

2) ada nilai dasar yang berarti bagi masyarakat karena menyangkut harga diri

3) pelayanan dapat diberikan dengan biaya yang murah

4) katalisator untuk program selanjutnya

5) mendorong tanggung jawab

6) menjamin kebutuhan yang dirasakan masyarakat telah dilibatkan

7) pekerjaan dilaksanakan dengan arah yang benar

8) menghimpun dan memenfaatkan berbagai pengetahuan yang ada di masyarakat perpaduan keahlian

9) membebaskan orang dari ketergantungan terhadap keahlian orang lain

10) lebih menyadarkan terhadap penyebab sehingga timbul kesadaran terhadap usaha untuk mengatasinya

Meskipun demikian, partisipasi bukanlah sebuah kenyataan yang dapat terjadi begitu saja. Ada prasyarat untuk terjadinya partisipasi, yaitu:

1) Kebebasan untuk berpartisipasi, yaitu otonomi

2) Kemampuan nyata untuk berpartisipasi

3) Kehendak untuk berpartisipasi

Bagaimana pun juga, kemungkinan untuk berpartisipasi sudah ada dan dimiliki oleh masyarakat. Semua bentuk masyarakat memiliki kearifan lokal yang sudah tumbuh dan terpelihara dalam kehidupan masyarakat. Kearifan lokal merupakan pengetahuan yang berkembang dalam masyarakat sebagai pendukung nilai-nilai yang ada dalam masyarakat. Perhatian terhadap adanya kearifan lokal masyarakat seringkali luput sebagai akibat dari adanya kepentingan-kepentingan pragmatis dari semua pihak yang terlibat dalam proses community development. Implikasinya adalah kearifan lokal masyarakat terkikis oleh nilai-nilai baru yang kurang menguntungkan dan secara tidak disadari terinternalisasi dalam masyarakat.

\section{Hasil Penelitian}

Peran serta masyarakat dalam usaha-usaha konservasi erat kaitannya dengan berbagai hal seperti pendidikan, adat istiadat, lingkungan hidupnya, dan lain-lain. 
Pendidikan memegang peranan sangat penting dalam usaha-usaha konservasi lingkungan hidup, melalui pendidikan masyarakat bisa mengetahui dampak dari kegiatan yang selama ini telah mereka lakukan terhadap lingkungan, apakah kegiatan-kegiatan tersebut sifatnya konservatif atau destruktif. Di daerah hulu sungai Citanduy terutama di kecamatan Padaherang dan kecamatan Cimanggu yang di tentukan sebagai daerah penelitian, sebagian besar warganya hanya tamatan SD saja, apalagi di daerah yang secara geografis berada di pedalaman atau pegunungan yang berarti jauh dari pusat pemerintahan dan pusat kecamatan, hampir semua penduduknya hanya tamatan SD, hal ini dikarenakan di daerah yang bisa dikatakan terpencil tersebut tidak ada sarana pendidikan yang memadai bahkan untuk menempuh jenjang SMP harus menempuh perjalanan yang jauh, padahal masyarakat di daerah tersebut memegang peranan penting dalam menjaga kelestarian Laguna Sagara Anakan. Dari daerah hulu inilah yang berkontribusi besar memberikan sedimentasi yang intensif karena kurangnya pengetahuan tentang konservasi dan cara mengolah lahan yang baik dan ramah lingkungan.

Kurangnya pengetahuan tentang konservasi dari bangku sekolah tidak diimbangi pula oleh program-program pemerintah yang berkaitan dengan konservasi seperti penyuluhan, workshop, ataupun sekedar himbauan untuk menjaga kelestarian lingkungan. Hal ini menyebabkan kesadaran warga untuk menjaga lingkungan menjadi sedikit sekali, hampir semua penduduk di sekitar Hulu Sungai Citanduy hanya berperan aktif menjaga lingkungan jika manfaat menjaga lingkungan itu bisa dirasakan secara langsung oleh mereka. Sebagai contoh, warga-warga yang berperan aktif menjaga kebersihan sungai hanya mereka yang rumahnya berada di pinggir sungai atau warga yang sawahnya terairi secara langsung dari sungai itu, sedangkan warga lain yang jauh dari sungai dan tidak mempunyai lahan garapan yang terairi langsung oleh sungai bersikap acuh tak acuh terhadap sungai, mereka tidak peduli dengan keadaan sungai yang mulai rusak ataupun sungai yang mengering bila musim kemarau datang.

Dari beberapa kegiatan konservasi yang biasa dilakukan, hanya penghijauan hutan yang dilaksanakan oleh hampir semua warga, karena mereka mengetahui bahwa dengan menanam pohon maka kebutuhan mereka terhadap air bisa terpenuhi, tapi penanaman pohon itu pun dilakukan hanya jika ada program dari pemerintah jadi bukan karena kesadaran yang tumbuh dari masing-masing individu tersebut, akan tetapi kaidah-kaidah untuk menanam pohon dengan baik tersebut tidak diterapkan dalam kegiatan mengolah lahan mereka sehari-hari, seperti memanfaatkan lahan pekarangan terutama lahan kering.

Beberapa petani memanfaatkan lahan kering mereka dengan menanami berbagai jenis tanaman yang tumbuhnya lama dan mempunyai daya konservatif tinggi karena berfungsi sebagai penyimpan cadangan air seperti albasia, jati, mahoni, dan lain-lain, tetapi mereka tidak memakai teknik konservasi dalam mengolah lahan kering mereka seperti sengkedan atau terasering, mereka hanya menggunakan teknik sengkedan atau terasering hanya pada lahan basah (sawah), sehingga ketika musim hujan datang tingkat erosi dari daerah hulu tersebut sangat tinggi, hal ini bisa terlihat dari berubahnya warna air secara drastis dari bening 
menjadi keruh dengan sangat cepat bila hujan turun. Tingkat erosi yang sangat tinggi dari daerah hulu akan menyebabkan sedimentasi yang sangat intensif di daerah hilir, pada kasus ini seperti yang terjadi di Laguna Sagara Anakan, sedimentasi yang intensif menyebabkan terjadinya pendangkalan dan timbulnya tanah-tanah baru. Tanah baru yang timbul itu menyebabkan banyak sekali persengketaan antara warga sekitar dengan pihak pemerintah, maupun antar warga sendiri.

Partisipasi yang diberikan oleh masyarakat di Kecamatan Padaherang dan Kecamatan Cimanggu sebagian besar berupa tenaga, hal ini dikarenakan berbagai faktor, salah satunya tidak ada pengetahuan yang cukup tentang konservasi sehingga tidak ada kesadaran untuk menjaga lingkungan yang tumbuh dari dalam diri mereka sendiri. Partisipasi tenaga ini diberikan pada saat ada program penghijauan dari pemerintah, dimana pemerintah memberikan dahulu penyuluhan berupa tata cara untuk melakukan penanaman kepada masyarakat dan setelah itu memberikan bibit tanaman, lalu warga yang ikut melakukan penanaman diberi upah sebesar Rp 20.000 sampai waktu Dzuhur.

Sedikitnya frekuensi pemerintah memberikan penyuluhan tentang konservasi, khususnya informasi tentang sagara anakan berperan besar juga kepada pendangkalan di sagara anakan, hampir sebagian besar warga di kecamatan Cimanggu dan kecamatan Padaherang tidak mengetahui apa itu sagara anakan, apalagi permasalahan yang timbul di sagara anakan mereka sama sekali tidak mengetahuinya, padahal perilaku mereka sehari-hari lah yang justru memberikan kontribusi yang besar kepada permasalahan yang timbul di laguna sagara anakan sekarang ini.

Berdasarkan hasil penelitian dan hasil pengujian statistik partisipasi masyarakat memiliki pengaruh secara simultan terhadap keberhasilan program konservasi, hal ini dapat dilihat dari persentase partisipasi yang diberikan oleh masyarakat di Kecamatan Padaherang dan Kecamatan Cimanggu. Bentuk partisipasi yang bisa diberikan bisa berupa ide/pikiran, barang, uang, tenaga, keahlian, dan sosial (Sungkawa 2004:82), keberhasilan program konservasi ditentukan oleh berbagai factor yang meliputi sumber daya manusia, program pembinaan keterampilan, dan pengerahan sumber daya organisasi lainnya.

Dari hasil penelitian tersebut dapat diketahui bahwa partisipasi bukanlah sebagai input (faktor) yang dapat mempengaruhi proses konservasi tetapi faktor pemerintahlah yang lebih dominan dalam menentukan keberhasilan/kegagalan program konservasi, artinya program konservasi tidak akan tercapai jika hanya datang dari pemerintah saja tapi haruslah ditumbuhkembangkan pasrtisipasi masyarakat secara efektif. Untuk itu partisipasi dalam kegiatan konservasi haruslah terus dikembangkan dari arus bawah.

Kualitas SDM sangatlah juga berpengaruh terhadap keberhasilan/kegagalan program konservasi. Rendahnya kualitas SDM yang dimiliki masyarakat di Kecamatan Padaherang dan Cimanggu cenderung mengakibatkan tidak berhasilnya program-program konservasi. Dari temuan di lapangan umumnya masyarakat tidak 
mengetahui apa itu konservasi atau tidak memiliki pengetahuan tentang konservasi yang memadai.

Mengingat SDM merupakan faktor yang penting dalam upaya konservasi, hal yang dapat dilakukan adalah bahwa orientasi konservasi lingkungan haruslah diprioritaskan pada upaya peningkatan kualitas SDM. Upaya ini dapat dilakukan dengan pemberian kesempatan yang luas kepada penduduk di Kecamatan Padaherang dan Cimanggu untuk bersekolah ke jenjang yang lebih tinggi. Sedangkan upaya untuk peningkatan non-formal dapat dilakukan dengan semakin seringnya intensitas pemberian diklat atau penyuluhan tentang konservasi, sebab selama ini masyarakat di sana belum seluruhnya mendapat kesempatan mengikuti diklat atau penyuluhan-penyuluhan yang diselenggrakan pemerintah ataupun swasta.

Dari penelitian yang dilakukan di kecamatan Padaherang dan Cimanggu, melihat bentuk partisipasi yang dilakukan masyarakat memiliki perbedaan. Dari ketiga sampel status mata pencaharian penduduk yaitu petani, pengusaha dan pedagang dapat terlihat dengan jelas setelah dilakukan pengolahan data. Mengenai bentuk partisipasi yang telah dijelaskan di atas hubungannya dengan kegiatan kegiatan konservasi terdapat persentasi yang berbeda, di bawah ini disajikan persentasi bentuk partisipasi masyarakat antara kecamatan Padaherang dan Cimanggu dari masing-masing mata pencaharian penduduk:

\begin{tabular}{|c|c|c|c|c|c|c|}
\hline \multirow[b]{2}{*}{ Bentuk Partisipasi } & \multicolumn{2}{|c|}{ Ide/pikiran } & \multicolumn{2}{|c|}{ Barang } & \multicolumn{2}{|c|}{ Ltang } \\
\hline & $\begin{array}{c}\text { Kec. } \\
\text { Patherang }\end{array}$ & $\begin{array}{c}\text { Kec. } \\
\text { Gimanggs }\end{array}$ & $\begin{array}{c}\text { Kec. } \\
\text { Padaherang }\end{array}$ & $\begin{array}{c}\text { Kec. } \\
\text { Gimanggs }\end{array}$ & $\begin{array}{c}\text { Kec. } \\
\text { Padaherang }\end{array}$ & $\begin{array}{c}\text { Kec. } \\
\text { Cimanggu }\end{array}$ \\
\hline $\begin{array}{l}\text { Sosialisas honsenasi } \\
\text { oleh pemerintahi } \\
\text { organisasi/LSM }\end{array}$ & $12.06 \%$ & $1133 \%$ & $12.65 \%$ & $800 \%$ & $824 \%$ & $15.33 \%$ \\
\hline $\begin{array}{l}\text { Penghijauan daerah } \\
\text { hutan }\end{array}$ & $4.12 \%$ & $600 \%$ & $5.00 \%$ & $1533 \%$ & $500 \%$ & $14.67 \%$ \\
\hline $\begin{array}{l}\text { Perbaikan } \\
\text { selokankanitasi }\end{array}$ & $7.35 \%$ & $6.67 \%$ & $4.71 \%$ & $800 \%$ & $588 \%$ & $13.33 \%$ \\
\hline $\begin{array}{l}\text { Penanaman lahan } \\
\text { pekarangan }\end{array}$ & $9.41 \%$ & $867 \%$ & $4.71 \%$ & $800 \%$ & $471 \%$ & $12.67 \%$ \\
\hline $\begin{array}{l}\text { Penanaman lahan kritis } \\
\text { Menjaga kerberadaan } \\
\text { hutan }\end{array}$ & $\begin{array}{l}6.47 \% \\
5.29 \%\end{array}$ & $\begin{array}{l}600 \% \\
1000 \%\end{array}$ & $\begin{array}{l}9.71 \% \\
6.76 \%\end{array}$ & $\begin{array}{l}1200 \% \\
800 \%\end{array}$ & $\begin{array}{l}4.71 \% \\
6.18 \%\end{array}$ & $\begin{array}{l}8.67 \% \\
14.67 \%\end{array}$ \\
\hline $\begin{array}{l}\text { Reboisas hutan } \\
\text { lindung,penghijauan }\end{array}$ & $8.82 \%$ & $733 \%$ & $9.71 \%$ & $867 \%$ & $853 \%$ & $12.67 \%$ \\
\hline $\begin{array}{l}\text { Rencana kegiatan } \\
\text { konsenasi }\end{array}$ & $12.65 \%$ & $1400 \%$ & $8.82 \%$ & $1133 \%$ & $735 \%$ & $12.00 \%$ \\
\hline $\begin{array}{l}\text { Perbaikan/perreliharaan } \\
\text { jalan }\end{array}$ & $5.00 \%$ & $667 \%$ & $5.00 \%$ & $6.67 \%$ & $9.12 \%$ & $10.67 \%$ \\
\hline $\begin{array}{l}\text { Menjaga kebersikan } \\
\text { lingloungan }\end{array}$ & $4.12 \%$ & $533 \%$ & $8.24 \%$ & $1000 \%$ & $706 \%$ & $8.67 \%$ \\
\hline $\begin{array}{l}\text { Menjaga keamanan } \\
\text { lingloungan }\end{array}$ & $9.12 \%$ & $1200 \%$ & $5.00 \%$ & $800 \%$ & $6.76 \%$ & $6.00 \%$ \\
\hline $\begin{array}{l}\text { Pengadaan,pemeliharan } \\
\text { tesilitas kesehatan }\end{array}$ & $9.42 \%$ & $1133 \%$ & $10.88 \%$ & $1200 \%$ & $1529 \%$ & $11.33 \%$ \\
\hline $\begin{array}{l}\text { Pengadaan,pemeliharaan } \\
\text { tasilitas pendidikan }\end{array}$ & $8.53 \%$ & $1333 \%$ & $9.41 \%$ & $1333 \%$ & $1206 \%$ & $7.33 \%$ \\
\hline
\end{tabular}

*) Drs. Asep Mulyadi adalah Dosen Jurusan Pendidikan Geografi FPIPS-UPI 


\begin{tabular}{|c|c|c|c|c|c|c|}
\hline \multirow[b]{2}{*}{ Bentuk Partisip $\approx i$} & \multicolumn{2}{|c|}{ Tenaga } & \multicolumn{2}{|c|}{ Keahlian } & \multicolumn{2}{|c|}{ Sogial } \\
\hline & $\begin{array}{c}\text { Kec. } \\
\text { Padaherang }\end{array}$ & $\begin{array}{c}\text { Kec. } \\
\text { Ci manggu }\end{array}$ & $\begin{array}{c}\text { Kec. } \\
\text { Padaherang }\end{array}$ & $\begin{array}{c}\text { Kec. } \\
\text { Ci manggu }\end{array}$ & $\begin{array}{c}\text { Kec. } \\
\text { Padaherang }\end{array}$ & $\begin{array}{c}\text { Kec. } \\
\text { Ci manggu }\end{array}$ \\
\hline $\begin{array}{l}\text { Sosialis asikonservas i oleh } \\
\text { pemerintahorganis asiLSMM }\end{array}$ & $44.71 \%$ & $48.67 \%$ & $4.71 \%$ & $2.00 \%$ & $17.63 \%$ & $14.67 \%$ \\
\hline Penghijauan daerah hutan & $70.59 \%$ & $44.00 \%$ & $2.94 \%$ & $8.00 \%$ & $12.35 \%$ & $12.00 \%$ \\
\hline Perbakan selok anis anitasi & $61.47 \%$ & $56.00 \%$ & $5.00 \%$ & $4.00 \%$ & $15.59 \%$ & $12.00 \%$ \\
\hline $\begin{array}{l}\text { Penanaman lahan } \\
\text { pekarangan }\end{array}$ & $72.35 \%$ & $56.67 \%$ & $3.82 \%$ & $4.67 \%$ & $5.00 \%$ & $9.32 \%$ \\
\hline Penanaman lahan kritis & $60.88 \%$ & $56.33 \%$ & $2.65 \%$ & $4.00 \%$ & $15.58 \%$ & $14.00 \%$ \\
\hline Menjagakerberadaan hutan & $48.24 \%$ & $46.00 \%$ & $3.24 \%$ & $2.67 \%$ & $30.29 \%$ & $18.66 \%$ \\
\hline $\begin{array}{l}\text { Reboisasi hutan } \\
\text { lindung'penghijauan }\end{array}$ & $50.59 \%$ & $47.33 \%$ & $5.00 \%$ & $6.00 \%$ & $17.35 \%$ & $18.00 \%$ \\
\hline Rencanakegiatan konservasi & $33.24 \%$ & $33.33 \%$ & $5.00 \%$ & $4.67 \%$ & $32.94 \%$ & $24.67 \%$ \\
\hline Perbakanpemelihar aan jal an & $54.12 \%$ & $46.67 \%$ & $5.00 \%$ & $7.32 \%$ & $21.76 \%$ & $22.00 \%$ \\
\hline $\begin{array}{l}\text { Menjagakebersihan } \\
\text { lingkungan }\end{array}$ & $67.94 \%$ & $54.67 \%$ & $3.82 \%$ & $5.33 \%$ & $8.82 \%$ & $16.00 \%$ \\
\hline $\begin{array}{l}\text { Menjagakeamanan } \\
\text { lingkungan }\end{array}$ & $65.59 \%$ & $58.00 \%$ & $3.24 \%$ & $6.00 \%$ & $10.29 \%$ & $10.00 \%$ \\
\hline $\begin{array}{l}\text { Pengadaan'pemeliharaan } \\
\text { fasilitas kesehatan }\end{array}$ & $22.94 \%$ & $41.34 \%$ & $3.82 \%$ & $6.00 \%$ & $37.65 \%$ & $18.00 \%$ \\
\hline $\begin{array}{l}\text { Pengadaanipemeliharaan } \\
\text { fasilitas pendidkan }\end{array}$ & $23.53 \%$ & $35.34 \%$ & $5.29 \%$ & $4.67 \%$ & $41.18 \%$ & $26.00 \%$ \\
\hline
\end{tabular}

Bentuk partisipasi ide dalam bebarapa kegiatan konservasi yang menduduki posisi yang tinggi adalah pada rencana kegiatan konservasi dengan $14 \%$ terdapat di kecamatan Cimanggu. Kondisi ini sangat dipengaruhi oleh latar belakang tingginya tingkat pendidikan masyarakat, dimana lulusan perguruan tinggi frekuensinya lebih banyak daripada masyarakat di kecamatan Padaherang.

Barang atau benda merupakan sesuatu yang setiap orang memilikinya, baik benda itu sifatnya bergerak maupun tak bergerak. Pada dasarnya bentuk partisipasi dengan barang berkaitan dengan kondisi ekonomi setiap individunya. Setiap individu memiliki tingkat kepemilikan yang berbeda-beda hal ini dapat mempengaruhi dalam setiap kegiatan kemasyarakatan terutama dalam kegiatan konservasi. Bentuk partisipasi barang di kecamatan Padaherang dan Cimanggu dalam kegiatan konservasi beranekaragam. Proporsi yang tertinggi terdapat di kecamatan Cimanggu yaitu pada kegiatan penghijauan hutan dengan persentasi 15,33\%. Hal ini mengindikasikan bahwa kepemilikan barang masyarakat kecamatan Cimanggu tinggi daripada kecamatan Padaherang. Akan tetapi nilai persentasi yang tinggi di kecamatan Padaherang yaitu pada kegiatan sosialisasi konservasi.

Sedangkan bentuk partisipasi uang hampir sebagian besar masyarakat kecamatan Cimanggu rata dalam beberapa kegiatan konservasi. Persentasi yang tinggi dalam kegiatan sosialisasi konservasi, akan tetapi persentasi di kecamatan Padaherang dapat dikategorikan rata, akan tetapi bila dilihat secara keseluruhan kecamatan Cimanggu yang paling tinggi.

Tenaga merupakan kekuatan yang setiap individu memilikinya. Kaitannya dengan partisipasi masyarakat dalam kegiatan konservasi berdasrakan penelitian yang disajikan melalui grafik diatas dapat dijelaskan bahwa kecamatan Cimanggu menduduki nilai yang tinggi bila dilihat secara kesuluruhan. Kegiatan sosialisasi 
memiliki nilai yang tinggi di kecamatan Cimanggu dalam bentuk partisipasi tenaga. Hal ini didorong dengan jumlah penduduk yang lebih besar daripada kecamatan Padaherang. Namun di kecamatan Padaherang dalam kegiatan penyediaan prasarana kesehatan memilki nilai yang tinggi dengan bentuk tenaga, kemungkinan hal ini terjadi karena masyarakatnya mengetahui tentang kesehatan.

masyarakatnya mengetahui tentang kesehatan.

Berhubungan dengan keahlian masyarakat identik dengan pendidikan yang dimilki oleh setiap individu. Dalam bentuk keahlian posisi yang tinggi di kecamatan Padaherang yaitu pada kegiatan penanaman lahan pekarangan sedangkan di kecamatan Cimanggu pada kegiatan menjaga kebersihan lingkungan. Partisipasi dalam bentuk sosial di kecamatan Padaherang masyarakat lebih berpartisipasi dalam memfasilitasi/menjaga fasilitas pendidikan sedangkan dikecamatan masyarakat lebih berpartisipasi dalam menjaga keberadaan hutan hal ini disebabkan karena fasilitas pendidikan di Cimanggu lebih sedikit dibandingkan dengan Padaherang.

\section{Penutup}

Partisipasi masyarakat memiliki pengaruh secara simultan terhadap keberhasilan program konservasi, hal ini dapat dilihat dari persentase partisipasi yang diberikan oleh masyarakat di Kecamatan Padaherang dan Kecamatan Cimanggu. Bentuk partisipasi yang bisa diberikan bisa berupa ide/pikiran, barang, uang, tenaga, keahlian, dan sosial. Keberhasilan program konservasi ditentukan oleh berbagai factor yang meliputi sumber daya manusia, program pembinaan keterampilan, dan pengerahan sumber daya organisasi lainnya.

Hasil penelitian menunjukkan bahwa partisipasi bukanlah sebagai input (faktor) yang dapat mempengaruhi proses konservasi tetapi faktor pemerintahlah yang lebih dominan dalam menentukan keberhasilan/kegagalan program konservasi, artinya program konservasi tidak akan tercapai jika hanya datang dari pemerintah saja tapi haruslah ditumbuhkembangkan pasrtisipasi masyarakat secara efektif. Untuk itu partisipasi dalam kegiatan konservasi haruslah terus dikembangkan dari arus bawah.

Kualitas SDM sangatlah juga berpengaruh terhadap keberhasilan/kegagalan program konservasi. Rendahnya kualitas SDM yang dimiliki masyarakat di Kecamatan Padaherang dan Cimanggu cenderung mengakibatkan tidak berhasilnya program-program konservasi. Dari temuan di lapangan umumnya masyarakat tidak mengetahui apa itu konservasi atau tidak memiliki pengetahuan tentang konservasi yang memadai.

Mengingat SDM merupakan faktor yang penting dalam upaya konservasi, hal yang dapat dilakukan adalah bahwa orientasi konservasi lingkungan haruslah diprioritaskan pada upaya peningkatan kualitas SDM. Upaya ini dapat dilakukan dengan pemberian kesempatan yang luas kepada penduduk di Kecamatan Padaherang dan Cimanggu untuk bersekolah ke jenjang yang lebih tinggi. Sedangkan upaya untuk peningkatan non-formal dapat dilakukan dengan semakin 
seringnya intensitas pemberian diklat atau penyuluhan tentang konservasi, sebab selama ini masyarakat di sana belum seluruhnya mendapat kesempatan mengikuti diklat atau penyuluhan-penyuluhan yang diselenggrakan pemerintah ataupun swasta. Diyakini dengan diberikannya masyarakat setempat pendidikan atau pelatihan-pelatihan yang memadai, maka kualitas sumber daya manusia mereka akan meningkat, pada gilirannya keberhasilan program konservasi pun akan tercapai.

\section{Daftar Pustaka :}

Badan Pengelola Kawasan Segara Anakan (BPKSA) - Cilacap, Mengelola Segara Anakan Yang Lestai dan Mandiri, Laporan Akhir Proyek Konservasi dan Pembangunan Segara Anakan.

Laporan Praktikum Kerja Lapangan Tahun 2008, Jurdik Geografi FPIPS UPI

Davis Keith, Newstroom, John W., Perilaku dalam Organisasi. Edisi ke tujuh. Jakarta: Terjemahan Erlangga, 1995.

Slamet, Y. 1994. Pembangunan Masyarakat Berwawasan Partisipasi. Surakarta: Sebelas Maret Univ. Press.

Suripin. 2002. Pelestarian Sumber daya Tanah Dan Air. Yogyakarta: ANDI.

Suhardjo,A.J.2008.Geografi Pedesaan.Yogyakarta: Universitas Gajah Mada.

Kecamatan Padaherang dan Cimanggu, Monografi Desa Tahun 2007. 